\title{
Analisis Spasial Kasus COVID-19 sampai dengan PPKM Jilid Dua
}

\author{
Studi Kasus di Pulau Jawa dan Bali
}

\author{
(Spatial Analysis of COVID-19 Cases until ELCA Phase Two - Case Study in The Island of Java \\ and Bali)
}

Arrazi Rahadiyan ${ }^{1 *}$, Ernawati Pasaribu ${ }^{2}$

${ }^{1,2}$ Politeknik Statistika STIS

Jalan Otto Iskanardinata No.64C, Kota Jakarta Timur, DKI Jakarta 13330

E-mail:211709575@stis.ac.id

\begin{abstract}
ABSTRAK
Pandemi COVID-19 merupakan penyebaran wabah penyakit menular COVID-19 yang diakibatkan oleh infeksi SARSCoV-2 di semua negara termasuk Indonesia. Pada 31 Maret 2020, diterbitkan Peraturan Pemerintah Nomor 21 Tahun 2020 tentang pembatasan sosial berskala besar untuk membatasi mobilitas orang dan barang. Setelah diterbitkan peraturan tersebut, kasus COVID-19 masih mengalami peningkatan yang signifikan. Oleh karena itu, Pemerintah Daerah menetapkan kebijakan karantina di beberapa wilayah di Pulau Jawa dan Bali berdasarkan Instruksi Mendagri Nomor 1 Tahun 2021 tentang Pemberlakuan Pembatasan Kegiatan Masyarakat (PPKM) Jilid 1 dan Jilid 2. Penelitian ini bertujuan untuk mengetahui gambaran umum, mengidentifikasi keragaman spasial, dan menganalisis faktor-faktor yang memengaruhi karakteristik spasial kasus COVID-19 di Pulau Jawa dan Bali sampai dengan masa PPKM Jilid 2 dengan Geographically Weighted Negative Binomial Regression (GWNBR). Hasil analisis menunjukkan terdapat keragaman spasial kasus COVID-19 di Pulau Jawa dan Bali. Kepadatan penduduk berpengaruh secara signifikan di seluruh kabupaten/kota, sedangkan rasio tenaga kesehatan per 1000 penduduk, indeks kualitas udara, dan pengeluaran kesehatan berpengaruh secara signifikan di beberapa kabupaten/kota di Pulau Jawa dan Bali.
\end{abstract}

Kata kunci: COVID-19, PPKM, GWNBR

\begin{abstract}
The COVID-19 pandemic is the spread of a disease outbreak infectious COVID-19 caused by infection with SARS-CoV2 in all countries including Indonesia. As of March 31, 2020, Government Regulation Number 21 of 2020 about LargeScale Social Restrictions to limit the mobility of people and goods. After the regulation was issued, COVID-19 cases still experienced a significant increase. Consequently, Governments in each region as well establish quarantine policies in several areas on the islands of Java and Bali based on the Instruction of the Minister of Home Affairs Number 1 of 2021 concerning the Enforcement of Limitations on Community Activities (ELCA) phase 1 and phase 2. This study aims to determine the general description, identify spatial diversity, and analyze factors that influence spatial characteristics of cases COVID-19 in Java and Bali until the period ELCA Phase 2 with Geographically Weighted Negative Binomial Regression (GWNBR). The results of the analysis show that there is a spatial diversity of COVID-19 cases in Java and Bali until the ELCA Phase 2. Density of population that significant effect in all districts/cities in Java, meanwhile the ratio of health workers per 1000 population, air quality index, and health spending has a significant effect only in a few districts/cities on the island Java and Bali.
\end{abstract}

Keywords: COVID-19, ELCA, GWNBR

\section{PENDAHULUAN}

Pada 31 Desember 2019, Kantor World Health Organization (WHO) yang berlokasi di China melaporkan kasus pneumonia yang belum diketahui penyebabnya di Kota Wuhan, Provinsi Hubei, China dan kemudian pada 7 Januari 2020 China mengidentifikasi kasus tersebut sebagai kasus coronavirus (Kementerian Kesehatan, 2020). Kurang dari satu bulan, coronavirus dari manusia ke manusia telah menyebar ke berbagai negara di dunia (Berta et al., 2020). WHO (2020), pada 30 Januari 2020 menetapkan Coronavirus Disease 2019 (COVID-19) sebagai pandemi (Kementerian Kesehatan, 2020).

Pandemi COVID-19 adalah peristiwa menyebarnya wabah COVID-19 di semua negara termasuk di Indonesia. Wabah ini disebabkan oleh virus jenis baru yang disebut Severe Acute Respiratory Syndrome Coronavirus 2 (SARS-CoV-2), di mana virus ini menyebabkan penyakit pada manusia terutama penyakit infeksi saluran pernapasan, mulai dari flu biasa hingga penyakit serius. Tanda dan gejala umum seseorang terinfeksi COVID-19 salah satunya adalah gejala gangguan pernapasan akut seperti demam, batuk, dan sesak napas (Kementerian Kesehatan, 2020). 
Kasus COVID-19 pertama di Indonesia dikonfirmasi pada 2 Maret 2020 dengan terinfeksinya dua warga Kota Depok, Provinsi Jawa Barat. Pada 15 Maret 2020, Indonesia mencapai 117 kasus terkonfirmasi COVID-19 dan Presiden Joko Widodo mengumumkan kepada penduduk Indonesia untuk melakukan langkah-langkah pembatasan sosial guna mengurangi penyebaran COVID-19 (Sekretariat Presiden, 2020). Pada 31 Maret 2020, Presiden Joko Widodo menandatangani Peraturan Pemerintah Nomor 21 Tahun 2020, yang mengatur Pembatasan Sosial Berskala Besar (PSBB) sebagai respon terhadap COVID-19. Selanjutnya, terdapat Keputusan Presiden Nomor 11 Tahun 2020 yang menyatakan pandemi COVID-19 sebagai bencana nasional. Pembuatan kedua peraturan tersebut didasarkan pada Undang-Undang Nomor 6 Tahun 2018 tentang kekarantinaan kesehatan, yang mengatur ketentuan mendasar untuk PSBB.

Pemerintah di tiap-tiap provinsi juga menetapkan kebijakan karantina di beberapa wilayah di Pulau Jawa dan Bali berdasarkan Instruksi Mendagri Nomor 1 Tahun 2021 tentang Pemberlakuan Pembatasan Kegiatan Masyarakat (PPKM) untuk pengendalian penyebaran COVID-19. Pemerintah mengganti istilah PSBB dengan PPKM. Meskipun demikian, penambahan kasus konfirmasi COVID-19 aktif perharinya masih mengalami peningkatan yang signifikan.

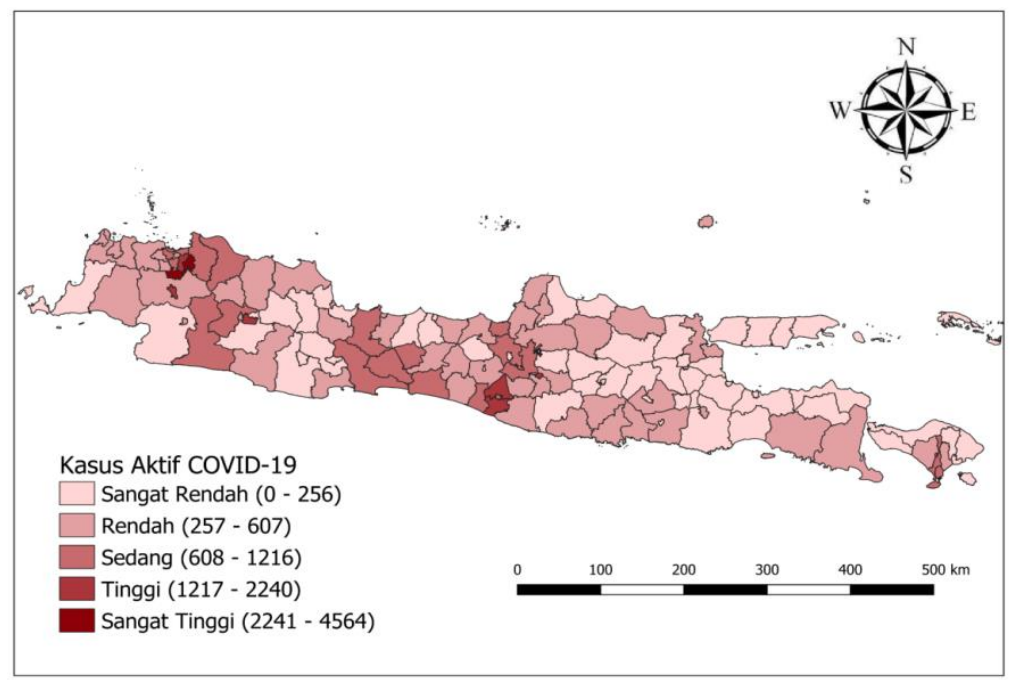

Sumber: datawrapper KawalCovid-19

Gambar 1. Kasus COVID-19 aktif 26 Januari 2021 menurut Kabupaten/Kota di Pulau Jawa dan Bali.

Gambar 1 menunjukkan sebaran kasus konfirmasi COVID-19 aktif per tanggal 26 Januari 2021 setelah penerapan PPKM Jilid 1 yang berlangsung selama 2 minggu. Kasus tertinggi terdapat di Kota Bekasi sebanyak 4.654 kasus, sedangkan kasus terendah terdapat di Kabupaten Bandung yaitu 1 kasus. Beberapa kabupaten/kota dengan kasus aktif COVID-19 tinggi yaitu Kota Jakarta Timur, Kota Bekasi, Kota Depok, Kota Bogor, Kota Yogyakarta, Kota Surakarta, dan Kabupaten Sleman. Sementara kabupaten/kota dengan kasus aktif COVID-19 rendah dan sangat rendah tersebar di seluruh wilayah di Pulau Jawa dan Bali.

Setelah diterapkannya PPKM Jilid 1 di Pulau Jawa dan Bali yang berlangsung mulai dari 11 Januari 2021 hingga 25 Januari 2021, penambahan kasus konfirmasi COVID-19 aktif per harinya masih mengalami peningkatan yang signifikan. Oleh karena itu, pemerintah menerapkan PPKM Jilid 2 yang berlangsung selama dua minggu mulai dari 26 Januari 2021 hingga 8 Februari 2021. Dengan demikian, diperlukan penelitian untuk mengetahui faktor apa saja yang memengaruhi jumlah kasus konfirmasi COVID-19. Penelitian yang dilakukan oleh Mahdy (2020), menjelaskan bahwa faktor yang dianggap memengaruhi kasus COVID-19 di Provinsi Jawa Barat yaitu kepadatan penduduk dan beberapa variabel lainnya. Penelitian yang dilakukan oleh Zulkarnain dan Ramadani (2020), menjelaskan bahwa kualitas udara signifikan memengaruhi kasus COVID-19 di Pulau Jawa. Penelitian yang dilakukan oleh Marhamah dan Jaya (2020), menjelaskan bahwa variabel kepadatan penduduk, jumlah fasilitas pelayanan kesehatan, dan beberapa variabel lainnya signifikan memengaruhi jumlah kasus positif di Kota Bandung. Penelitian yang dilakukan oleh Fitriani dan Jaya (2020), menjelaskan bahwa kepadatan penduduk dan variabel lainnya memengaruhi penyebaran kasus COVID-19 di Jawa Timur. Penelitian yang dilakukan oleh Yusa (2020), pengeluaran kesehatan memengaruhi upaya dalam penanganan COVID-19.

Berdasarkan kasus COVID-19 yang terus mengalami peningkatan, beberapa penelitian menunjukkan bahwa kepadatan penduduk, kualitas udara, fasilitas pelayanan kesehatan, dan pengeluaran kesehatan memengaruhi jumlah kasus konfirmasi COVID-19. Penelitian ini bertujuan untuk memberikan gambaran umum kasus konfirmasi COVID-19 sampai dengan masa PPKM Jilid 2, mengidentifikasi keragaman spasial, 
dan menganalisis faktor-faktor yang memengaruhi karakteristik spasial jumlah kasus konfirmasi COVID-19 di Pulau Jawa dan Bali.

\section{METODE}

\section{Overdispersion}

Dalam pemodelan data count terdapat satu kondisi, di mana kesamaan nilai mean dan varians dari variabel respon sulit untuk terpenuhi. Kondisi tersebut dikenal sebagai equidispersion. Kondisi yang sering dijumpai pada data count adalah nilai varians lebih besar dari meannya. Kondisi tersebut dikenal sebagai overdispersion. Sementara apabila nilai varians lebih kecil dari nilai meannya, maka kondisi tersebut dikenal sebagai underdispersion. Overdispersion dibuktikan dengan nilai deviance atau Pearson Chi-Square dibagi dengan derajat bebasnya yang lebih besar dari 1 (McCullagh and Nelder, 1989). Terjadinya overdispersion pada data count akan berpengaruh pada nilai standard error, di mana nilai standard error dari estimasi menjadi turun (underestimate) apabila tetap menggunakan regresi poisson, sehingga kesimpulan yang dihasilkan akan menjadi tidak valid (Hilbe, 2011).

\section{Regresi Binomial Negatif}

Regresi Binomial Negatif merupakan suatu model regresi yang digunakan untuk menganalisis hubungan antara variabel respon berupa data count, baik dalam keadaan equidispersion maupun dalam keadaan overdispersion, dengan satu atau lebih variabel prediktor (Ismail dan Jemain, 2007). Hubungan antara variabel respon berupa data count yang terjadi overdispersion dengan variabel prediktornya dinyatakan ke dalam model regresi Binomial Negatif berikut ini:

$$
y_{i}=\mu_{i}+\varepsilon_{i}=e^{x_{i}^{\prime} \beta}+\varepsilon_{i}
$$

Model regresi Binomial Negatif diestimasi sebagai Generalized Linear Model (GLM), sehingga menghasilkan fungsi penghubung (link function) yang dituliskan dalam bentuk berikut (Hilbe, 2011):

$$
\begin{aligned}
& g\left(\mu_{i}\right)=\ln \left(\mu_{i}\right)=x_{i}^{\prime} \beta \ldots . . \\
& \mu_{i}=e^{x_{i}^{\prime} \beta} ; i=1,2, \ldots, n .
\end{aligned}
$$

Keterangan:

$\varepsilon_{i} \quad$ : error pada pengamatan ke- $i$

$\beta$ : vektor koefisien regresi

$x_{i}^{\prime}:$ nilai variabel prediktor ke- $i$

\section{Pengujian Asumsi Nonmultikolinieritas}

Multikolinieritas merupakan korelasi yang terjadi antar variabel prediktor. Oleh karena itu, pengujian nonmultikolinieritas dilakukan untuk mendeteksi tidak adanya hubungan antar variabel prediktor. Rumus Variance Inflation Factors (VIF) dinyatakan berikut ini:

$$
V I F_{k}=\left(1-R_{k}^{2}\right)^{-1}
$$

dengan $R_{k}^{2}$ adalah koefisien determinasi dari regresi variabel prediktor $X_{k}$ dengan variabel prediktor $X$ lain pada model. Apabila nilai VIF terbesar di antara semua variabel $X$ kurang dari 10 maka dapat disimpulkan tidak terjadi multikolinieritas.

\section{Heterogenitas Spasial}

Heterogenitas atau keragaman spasial terjadi akibat adanya perbedaan pengaruh variabel prediktor terhadap variabel respon yang diakibatkan oleh karakteristik wilayah. Uji heterogenitas spasial dilakukan untuk melihat apakah terdapat karakteristik pada setiap lokasi observasi/pengamatan, sehingga menghasilkan perbedaan parameter regresi secara parsial. Pengujian heterogenitas atau keragaman spasial dapat dilakukan dengan menggunakan statistik uji Breusch-Pagan (Anselin, 1998) dengan hipotesisnya berikut ini:

$\mathrm{H}_{0}: \sigma_{1}^{2}=\sigma_{2}^{2}=\cdots=\sigma_{n}^{2}=\sigma^{2} \quad$ (tidak ada perbedaan varians antar wilayah)

$\mathrm{H}_{1}$ : minimal ada satu $\sigma_{i}^{2} \neq \sigma^{2} \quad$ (ada perbedaan varians antar wilayah)

di mana statistik uji yang digunakan yaitu:

$$
B P=\left(\frac{1}{2}\right) \boldsymbol{f}^{T} \boldsymbol{Z}\left(\boldsymbol{Z}^{T} \boldsymbol{Z}\right)^{-1} \boldsymbol{Z}^{\boldsymbol{T}} \boldsymbol{f} \sim X_{(k-1)}^{2}
$$


dengan $\boldsymbol{f}=\left(f_{1}, f_{2}, \ldots, f_{n}\right)^{T}$; dari $f_{i}=\left(\frac{e_{i}^{2}}{\sigma^{2}}-1\right)$ dan $e_{i}=y_{i}-\hat{y}_{i}$

Keterangan:

$e_{i}^{2}:$ kuadrat sisaan (error) untuk observasi/pengamatan ke-i

$\mathbf{Z}$ : matriks berukuran $\mathrm{n} \times \mathrm{p}$ berisi vektor yang telah distandardisasi untuk setiap observasi/pengamatan

$\sigma^{2}: \sum_{1}^{n} e_{i}^{2}$ (ragam dari variabel y)

$k \quad:$ jumlah variabel prediktor

$i \quad$ : jumlah observasi/pengamatan

Keputusannya akan tolak Ho apabila nilai BP $>X_{(k-1)}^{2}$ atau p-value $<\alpha(0,05)$ yang berarti bahwa terdapat indikasi adanya perbedaan keragaman antar wilayah sehingga terjadi heterogenitas spasial.

\section{Bandwidth Optimum}

Bandwidth yang optimum diperlukan karena apabila bandwidth yang dipilih terlalu kecil, maka akan menyebabkan variasi yang besar, begitu juga sebaliknya. Hasil estimasi model Geographically Weighted Regression (GWR) tidak terlalu sensitif terhadap pemilihan fungsi penimbang, akan tetapi justru sangat sensitif terhadap pemilihan bandwidth dari fungsi penimbang yang dipilih. Oleh karena itu, penentuan nilai bandwidth yang optimum sangat diperlukan sebagai bagian dari penyusunan model GWR.

Kemudian, beberapa metode yang dapat digunakan dalam menentukan nilai bandwidth optimum, antara lain metode Cross Validation (CV) dan Akaike Information Criterion (AIC). Metode CV disarankan untuk regresi lokal oleh Cleveland (1979) dan juga disarankan untuk estimasi kepadatan kernel oleh Bowman (1984) dalam Fotheringham et al. (2002). Nilai CV diperoleh dari bentuk berikut ini:

$$
C V=\sum_{i=1}^{n}\left[y_{i}-\hat{y}_{\neq i}(b)\right]^{2}
$$

dengan $\hat{y}_{\neq i}(b)$ adalah nilai prediksi dari $y_{i}$ (fixed value) di mana nilai pengamatan untuk wilayah ke- $i$ tidak diikutsertakan dalam proses penghitungan jumlah kuadrat (kalibrasi model). Proses untuk meminimumkan nilai CV bisa dilakukan dengan menggunakan teknik Golden Section Search. Bandwidth optimum yang terpilih adalah bandwidth yang memiliki nilai CV minimum.

\section{Fungsi Kernel Adaptive Bi-square}

Berdasarkan nilai bandwidth optimum, fungsi kernel adaptive digunakan pada wilayah observasi atau amatan yang menyebar, karena besarnya penimbang akan disesuaikan dengan jumlah wilayah tetangga optimum yang dibutuhkan. Penimbang adaptive menerapkan bandwidth yang relatif kecil pada wilayah yang relatif sempit dan relatif berdekatan, sedangkan wilayah dengan lingkup luas dan berjauhan diberikan bandwidth yang relatif besar. Pembobot fungsi kernel dituliskan berikut ini:

$$
w_{i j}=\left\{\begin{array}{c}
{\left[1-\left(\frac{d_{i j}}{h}\right)^{2}\right]^{2}, \text { jika } d_{i j} \leq h} \\
0, d_{i j}>h
\end{array}\right.
$$

dengan $d_{i j}=\sqrt{\left(u_{i}-u_{j}\right)^{2}+\left(v_{i}-v_{j}\right)^{2}}$ adalah jarak euclidean dari lokasi $\left(u_{i}, v_{i}\right)$ ke lokasi $\left(u_{j}, v_{j}\right)$.

Keterangan:

$\left(u_{i}, v_{i}\right) \quad$ : titik lokasi pengamatan ke- $i$

$\left(u_{j}, v_{j}\right) \quad$ : titik lokasi pengamatan ke-j

$h \quad$ : parameter non negatif (bandwidth)

\section{Model Geographically Weighted Negative Binomial Regression (GWNBR)}

Model GWNBR adalah salah satu metode yang digunakan untuk melakukan pendugaan parameter pada data count yang terjadi overdispersion dan mengalami heterogenitas spasial. Parameter yang dihasilkan dari pemodelan dengan metode GWNBR bersifat lokal, di mana setiap wilayah observasi atau pengamatan akan mendapatkan parameter yang berbeda. Dalam model GWNBR, estimasi parameter yang dihasilkan bersifat lokal yaitu estimasi pada setiap wilayah observasi atau pengamatan. GWNBR memperluas kerangka regresi global yaitu dengan memungkinkan parameter lokal untuk diestimasi. Model GWNBR dituliskan berikut ini:

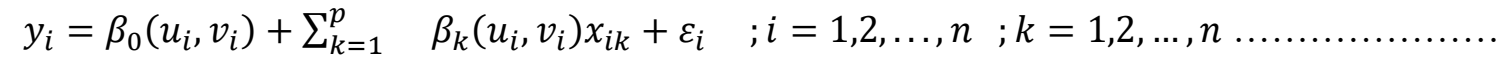


Keterangan:

$y_{i} \quad:$ nilai variabel respon pada wilayah ke-i

$x_{i k} \quad$ : nilai variabel prediktor ke-k pada wilayah ke-i

$\left(u_{i}, v_{i}\right) \quad$ : titik koordinat wilayah ke-i

$\beta_{0}\left(u_{i}, v_{i}\right)$ : nilai intersep pada wilayah ke-i

$\beta_{k}\left(u_{i}, v_{i}\right)$ : parameter variabel prediktor ke-k pada wilayah ke-i

$p \quad$ : banyaknya variabel prediktor

$\varepsilon_{i} \quad$ : error pada wilayah ke-i

\section{Data dan Sumber Data}

Dengan mempertimbangkan kelengkapan dan ketersediaan data, maka penelitian ini menggunakan 5 variabel berikut ini:

- Jumlah kasus konfirmasi COVID-19 sebagai variabel respon (Y) yang diperoleh dari datawrapper KawalCovid-19 melalui wrapper.dwcdn.net/BA77E/295/ pada 4 Februari 2021, serta empat variabel prediktor seperti

- Kepadatan penduduk (X1), diperoleh dari datawrapper KawalCovid-19 melalui wrapper.dwcdn.net/BA77E/295/ tahun 2020,

- Rasio tenaga kesehatan per 1000 penduduk (X2), diperoleh dari BPPSDM Kementerian Kesehatan 202031 Desember 2020,

- Indeks kualitas udara (X3), diperoleh dari AirVisual Mobile Android Application secara rata-rata pada 4 November 2020 sampai dengan 4 Februari 2021,

- Pengeluaran kesehatan per juta rupiah (X4), diperoleh dari data SUSENAS September 2020 diolah, serta dua variabel lokasi berupa koordinat geografis

\section{HASIL DAN PEMBAHASAN}

Gambaran Umum Jumlah Kasus Konfirmasi COVID-19, Kepadatan Penduduk, Rasio Tenaga Kesehatan Per 1000 Penduduk, Indeks Kualitas Udara, dan Pengeluaran Kesehatan Per Juta Rupiah

Pada bagian ini akan dibahas gambaran umum mengenai persebaran kasus konfirmasi COVID-19 per kabupaten/kota di Pulau Jawa dan Bali sampai dengan masa Pemberlakuan Pembatasan Kegiatan Masyarakat (PPKM) Jilid 2. Penjelasan mengenai gambaran umum tersebut akan ditampilkan menggunakan peta tematik dengan software QGIS 3.6.0.

\section{Kasus Konfirmasi COVID-19 di Pulau Jawa dan Bali sampai dengan masa PPKM Jilid 2}

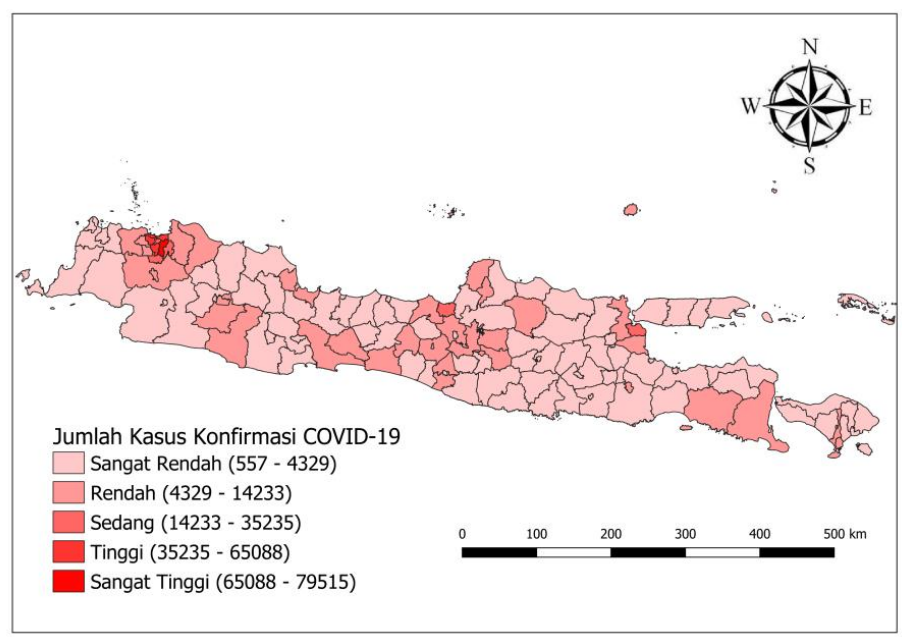

Gambar 2. Peta tematik jumlah kasus konfirmasi COVID-19 di Pulau Jawa dan Bali sampai dengan masa PPKM Jilid 2 (4 Februari 2021).

Berdasarkan Gambar 2 dapat dilihat persebaran jumlah kasus konfirmasi COVID-19 per kabupaten/kota di Pulau Jawa dan Bali sampai dengan masa PPKM Jilid 2 dengan 5 kategori menggunakan natural breaks yaitu sangat rendah, rendah, sedang, tinggi, dan sangat tinggi. Secara visual dapat dilihat 
bahwa jumlah kasus konfirmasi COVID-19 yang cenderung tinggi ada di beberapa kota dan menunjukkan adanya pengelompokkan dalam suatu wilayah. Kabupaten/kota dengan jumlah kasus konfirmasi COVID-19 tinggi dan sangat tinggi yaitu terdapat di Kota Jakarta Selatan, Kota Jakarta Barat, Kota Jakarta Utara, dan Kota Jakarta Timur, sedangkan kabupaten/kota dengan jumlah kasus konfirmasi COVID-19 sedang terdapat di Kota Jakarta Pusat, Kota Depok, Kota Bekasi, Kota Semarang, dan Kota Surabaya. Sementara kabupaten/kota lainnya memiliki jumlah kasus konfirmasi COVID-19 yang cenderung rendah. Secara umum, jumlah kasus konfirmasi COVID-19 di Pulau Jawa dan Bali sampai dengan masa PPKM Jilid 2 dengan kategori tinggi dan sangat tinggi berada di Provinsi DKI Jakarta dan sekitarnya.

\section{Identifikasi Heterogenitas Spasial Model Regresi Binomial Negatif Jumlah Kasus Konfirmasi COVID- 19 di Pulau Jawa dan Bali sampai dengan masa PPKM Jilid 2}

Model yang akan dikembangkan untuk menganalisis faktor-faktor yang memengaruhi jumlah kasus konfirmasi COVID-19 perlu mengidentifikasi adanya keragaman spasial antar kabupaten/kota. Terlebih dahulu dilakukan pengujian overdispersion untuk mengetahui model regresi yang tepat. Selanjutnya, model regresi yang dihasilkan dilakukan pengujian multikolinieritas dan heterogenitas spasial untuk mengetahui adanya keragaman spasial antar kabupaten/kota.

\section{Pengujian Overdispersion}

Dengan menggunakan program Rstudio, hasilnya menunjukkan bahwa parameter dispersion atau nilai rasio deviance dengan derajat bebasnya adalah sebesar 1252,737 dan lebih besar dari 1, sehingga dapat disimpulkan bahwa terdapat overdispersion pada model. Kesimpulan tersebut diperkuat dengan nilai $z$-score model $=3,8819$ dengan $p$-value $=5,182 \times 10^{-5}$. Sehingga pada taraf signifikansi $0,05\left(z_{(0,025)}=1,96\right)$ menghasilkan keputusan untuk tolak $\mathrm{H}_{0}$.

Hasil tersebut menunjukkan bahwa diperlukan model Regresi Binomial Negatif guna memodelkan jumlah kasus konfirmasi COVID-19 di Pulau Jawa dan Bali sampai dengan masa PPKM Jilid 2. Model tersebut tepat digunakan untuk mengatasi adanya overdispersion pada data count.

\section{Regresi Binomial Negatif}

Model Regresi Global Binomial Negatif digunakan sebagai akibat terjadinya kasus overdispersion pada variabel respon. Pemodelan dilakukan dengan menggunakan program Rstudio yang hasilnya ditunjukkan oleh tabel berikut:

Tabel 1. Model Regresi Binomial Negatif

\begin{tabular}{|c|c|c|c|c|}
\hline & Estimate & Std. Error & Z Value & $P$ Value \\
\hline (Intercept) & 6,2730 & 0,1438 & 43,6090 & 0,0000 \\
\hline Kepadatan Penduduk (X1) & $1,1110 \times 10^{-4}$ & $1,2530 \times 10^{-5}$ & 8,8650 & 0,0000 \\
\hline Rasio Tenaga Kesehatan Per 1000 Penduduk (X2) & 0,2289 & 0,0150 & 15,1680 & 0,0000 \\
\hline Indeks Kualitas Udara (X3) & $1,4580 \times 10^{-3}$ & $1,2780 \times 10^{-3}$ & 1,1410 & 0,2540 \\
\hline Pengeluaran Kesehatan Per Juta Rupiah (X4) & $3,0280 \times 10^{-4}$ & $3,3200 \times 10^{-5}$ & 9,1220 & 0,0000 \\
\hline
\end{tabular}

Berdasarkan hasil pengujian terhadap parameter Regresi Binomial Negatif pada tabel 1, dengan menggunakan taraf signifikansi $0,05\left(z_{(0,025)}=1,96\right)$, menunjukkan bahwa variabel kepadatan penduduk (X1), rasio tenaga kesehatan per 1000 penduduk (X2), dan pengeluaran kesehatan per juta rupiah (X4) signifikan berpengaruh terhadap jumlah kasus konfirmasi COVID-19 di Pulau Jawa dan Bali sampai dengan masa PPKM Jilid 2.

\section{Pengujian Asumsi Nonmultikolinieritas}

Pemenuhan asumsi nonmultikolinieritas merupakan salah satu syarat dalam melakukan pemodelan regresi. Pengujian dilakukan untuk mengetahui adanya hubungan yang saling memengaruhi antar variabel prediktor, sehingga pemeriksaan asumsi ini bertujuan untuk melakukan pemilihan variabel prediktor yang akan digunakan. Pendeteksian kasus multikolinieritas dilakukan dengan cara melihat nilai Variance Inflation Factors (VIF).

Tabel 2. Nilai VIF dari variabel prediktor

\begin{tabular}{cccc}
\hline $\mathrm{X} 1$ & $\mathrm{X} 2$ & $\mathrm{X} 3$ & $\mathrm{X} 4$ \\
\hline 2,3267 & 1,1891 & 1,0159 & 2,0989 \\
\hline
\end{tabular}


Dengan menggunakan rumus dan diolah dengan program Rstudio, maka dihasilkan nilai VIF seperti pada tabel 2. Seluruh variabel prediktor menghasilkan nilai VIF yang kurang dari 10, sehingga kesimpulan yang dihasilkan yaitu tidak terdapat kasus multikolinieritas. Dapat diartikan bahwa antar variabel prediktor tidak terdapat hubungan linier yang berarti. Dengan demikian, keempat variabel prediktor tersebut, di antaranya kepadatan penduduk (X1), rasio tenaga kesehatan per 1000 penduduk (X2), indeks kualitas udara (X3), dan pengeluaran kesehatan per juta rupiah (X4) dapat digunakan untuk memodelkan jumlah kasus konfirmasi COVID-19 di Pulau Jawa dan Bali sampai dengan masa PPKM Jilid 2.

\section{Pengujian Heterogenitas Spasial}

Selanjutnya, pengujian heterogenitas atau keragaman spasial dilakukan dengan software Rstudio dan menggunakan statistik uji Breusch-Pagan yang diperoleh nilai sebesar 49,07 dengan p-value sebesar 5,6470 $\mathrm{x} 10^{-10}$. Hal ini menunjukkan bahwa dengan tingkat signifikansi 0,05 yang menghasilkan daerah kritis $X_{(0,05 ; 4)}^{2}=9,4877$, terdapat heterogenitas spasial antar wilayah observasi. Sehingga terdapat perbedaan karakteristik dari suatu titik observasi atau pengamatan ke titik observasi atau pengamatan lainnya. Oleh karena itu, akan dihasilkan parameter yang berbeda-beda di setiap wilayah.

Adanya heterogenitas spasial pada data jumlah kasus konfirmasi COVID-19 di Pulau Jawa dan Bali sampai dengan masa PPKM Jilid 2 menyebabkan metode Regresi Global Binomial Negatif menjadi kurang tepat digunakan dalam pemodelan. Untuk itu, diperlukan metode yang mampu menghasilkan parameter lokal untuk masing-masing kabupaten/kota di Pulau Jawa dan Bali. Model regresi yang digunakan yaitu Geographically Weighted Negative Binomial Regression (GWNBR).

Analisis Faktor-Faktor Yang Memengaruhi Karakteristik Spasial Jumlah Kasus Konfirmasi COVID19 di Pulau Jawa dan Bali Sampai dengan masa PPKM Jilid 2 dengan Geographically Weighted Negative Binomial Regression (GWNBR)

\section{Pemilihan Bandwidth Optimum}

Pada lokasi penelitian ini yaitu Pulau Jawa dan Bali, titik pusat kabupaten/kota tersebar tidak merata karena ada yang padat dan ada yang jarang. Kabupaten/kota yang padat berada di wilayah perkotaan seperti Provinsi DKI Jakarta, Jawa Barat, Jawa Tengah, dan Jawa Timur. Sementara itu, sebaran titik pusat kabupaten/kota yang jarang terdapat di Kota Administrasi Kepulauan Seribu, Jawa Timur bagian Pulau Madura, Pulau Bali, dan Provinsi Banten serta Provinsi Jawa Barat bagian selatan. Oleh karena itu, dalam penelitian ini dipilih kernel adaptive bandwidth .

Dengan menggunakan kriteria evaluasi Cross Validation (CV), maka fungsi pembobot kernel yang digunakan yaitu kernel adaptive bisquare. Metode bisquare dipilih karena menghasilkan bandwidth yang optimum pada tiap-tiap kabupaten/kota. Metode ini dapat memberikan bandwidth optimum yang tidak terlalu besar dan juga tidak terlalu kecil.

\section{Estimasi Parameter dengan Model Geographically Weighted Negative Binomial Regression (GWNBR)}

Pemodelan GWNBR dapat dilakukan setelah pembentukan matriks pembobot spasial. Model GWNBR akan menghasilkan 512 estimasi koefisien parameter $\left(j_{\left(u_{i}, v_{i}\right)}\right)$ untuk 128 kabupaten/kota di Pulau Jawa dan Bali. Besaran nilai koefisien parameter tersebut dapat menunjukkan pengaruh dan perubahan yang terjadi pada jumlah kasus konfirmasi COVID-19 pada setiap perubahan kondisi variabel prediktor.

\section{Pengujian Parameter Model GWNBR Secara Simultan}

Pada tahap pertama, dilakukan pengujian secara simultan untuk melihat apakah terdapat setidaknya satu parameter yang secara signifikan berpengaruh dalam model. Pengujian dilakukan dengan membandingkan nilai deviance pada model GWNBR yang terbentuk dengan daerah kritis $X_{(0,05 ; 4)}^{2}=9,4877$. Berdasarkan hasil perhitungan, didapatkan nilai deviance pada model sebesar 318,2531. Karena diperoleh nilai deviance yang lebih besar dari nilai kritis $X_{(0,05 ; 4)}^{2}$, maka dengan menggunakan tingkat signifikansi 0,05 , hasil tersebut menunjukkan bahwa minimal terdapat satu parameter pada model yang berpengaruh secara signifikan terhadap jumlah kasus konfirmasi COVID-19 di Pulau Jawa dan Bali sampai dengan masa PPKM Jilid 2. 


\section{Pengujian Model GWNBR Secara Parsial}

Kemudian pada tahap kedua, dilakukan pengujian secara parsial dengan menggunakan uji z-score. Adanya heterogenitas spasial atau keragaman antar wilayah, maka akan menghasilkan nilai koefisien dan signifikansi parameter yang berbeda di tiap kabupaten/kota. Berdasarkan hasil pengujian parsial, variabel kepadatan penduduk signifikan di semua kabupaten/kota. Dengan kata lain, kepadatan penduduk memiliki pengaruh terhadap jumlah kasus konfirmasi COVID-19 secara global. Akan tetapi, tidak semua parameter yang dihasilkan pada tiap-tiap wilayah berpengaruh secara signifikan dalam memodelkan jumlah kasus konfirmasi COVID-19 di Pulau Jawa dan Bali sampai dengan masa PPKM Jilid 2. Sebagai contoh, perbandingan model GWNBR untuk Kota Bekasi dan Kab. Sukabumi. Kota Bekasi memiliki jumlah kasus konfirmasi COVID-19 sebanyak 25.449 kasus dengan semua variabel prediktor signifikan memengaruhi model, sedangkan Kab. Sukabumi memiliki jumlah kasus konfirmasi COVID-19 sebanyak 2.962 kasus dengan 2 variabel yang signifikan memengaruhi model. Persamaannya dituliskan dalam bentuk sebagai berikut:

$$
\begin{aligned}
& \hat{Y}_{\text {Kota Bekasi }}=\exp \left(6,2726+0,0001 X_{1}^{*}+0,2289 X_{2}^{*}+0,0034 X_{3}^{*}+0,0002 X_{4}^{*}\right) \\
& \hat{Y}_{\text {Kabupaten Sukabumi }}=\exp \left(6,2768+0,0004 X_{1}^{*}+0,2925 X_{2}^{*}-0,0005 X_{3}+0,0003 X_{4}\right)
\end{aligned}
$$

Keterangan:

* : variabel signifikan pada $\alpha(0,05)$

Kota Bekasi memiliki 4 variabel prediktor yang signifikan yaitu variabel kepadatan penduduk (X1), rasio tenaga kesehatan per 1000 penduduk (X2), indeks kualitas udara (X3), dan pengeluaran kesehatan per juta rupiah (X4), sedangkan Kab. Sukabumi memiliki 2 variabel prediktor yang signifikan yaitu variabel kepadatan penduduk (X1) dan rasio tenaga kesehatan per 1000 penduduk (X2). Pada variabel kepadatan penduduk (X1) di Kota Bekasi, setiap kenaikan sebanyak satu jiwa penduduk per kilometer persegi akan terjadi penambahan rata-rata dari jumlah kasus konfirmasi COVID-19 sebesar $\exp (0,0001)=1.0001$ kali dengan syarat bahwa variabel lainnya tetap. Sementara pada variabel kepadatan penduduk (X1) di Kab. Sukabumi, setiap kenaikan sebanyak satu jiwa penduduk per kilometer persegi akan terjadi penambahan rata-rata dari jumlah kasus konfirmasi COVID-19 sebesar $\exp (0,0001)=1.0004$ kali dengan syarat bahwa variabel lainnya tetap.

Kemudian, pada variabel rasio tenaga kesehatan (X2) di Kota Bekasi, setiap kenaikan sebanyak 1 jiwa tenaga kesehatan per 1000 penduduk akan terjadi penambahan rata-rata dari jumlah kasus konfirmasi COVID-19 sebesar $\exp (0,2289)=1,2572$ kali dengan syarat bahwa variabel lainnya tetap. Sementara pada variabel rasio tenaga kesehatan per 1000 penduduk (X2) di Kab. Sukabumi, setiap kenaikan sebanyak 1 jiwa tenaga kesehatan per 1000 penduduk akan terjadi penambahan rata-rata dari jumlah kasus konfirmasi COVID-19 sebesar $\exp (0,2925)=1,3397$ kali dengan syarat bahwa variabel lainnya tetap. Hal tersebut berlaku juga untuk variabel lainnya, di mana besar penambahan atau penurunan rata-rata jumlah kasus bergantung pada nilai koefisien dari setiap parameternya. Setiap kabupaten/kota memiliki nilai estimasi koefisien parameter yang berbeda.

\section{Pengelompokkan Wilayah Berdasarkan Variabel Prediktor Yang Signifikan}

Berdasarkan hasil pengujian secara parsial, diperoleh empat kelompok kabupaten/kota berdasar variabelnya yang berpengaruh secara signifikan terhadap jumlah kasus konfirmasi COVID-19 di Pulau Jawa dan Bali sampai dengan masa PPKM Jilid 2. Variabel yang signifikan memberikan pengaruh di semua wilayah yaitu kepadatan penduduk (X1). Sementara itu, variabel rasio tenaga kesehatan per 1000 penduduk (X2), indeks kualitas udara (X3) dan pengeluaran kesehatan per juta rupiah (X4) memberikan pengaruh terhadap jumlah kasus konfirmasi COVID-19 di sebagian besar wilayah. 


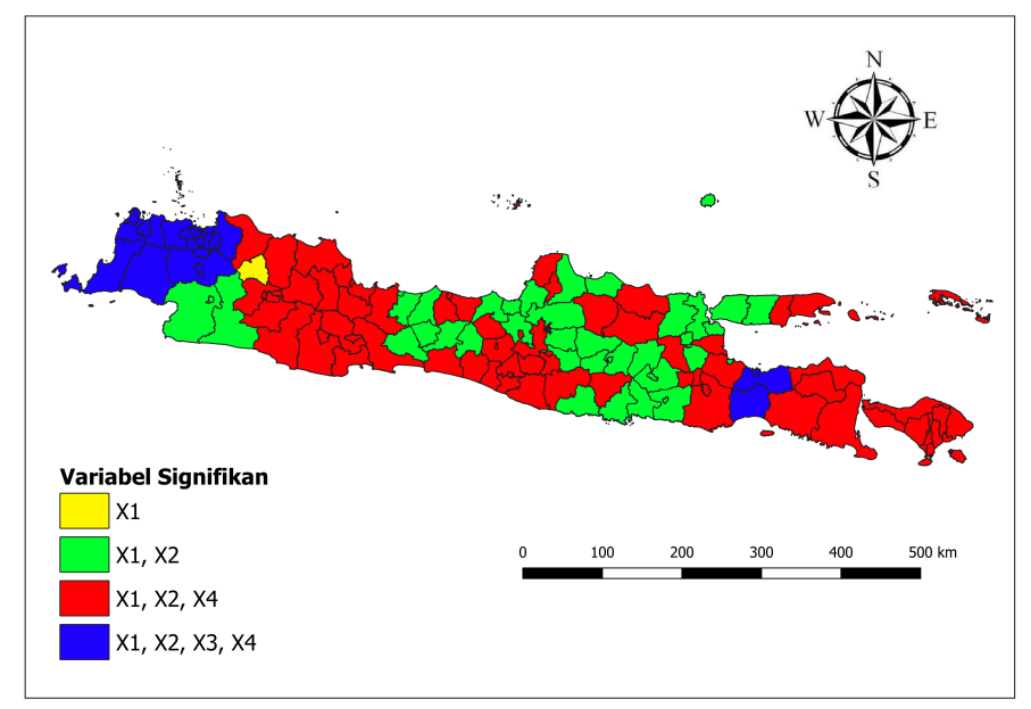

Gambar 3. Persebaran variabel prediktor yang berpengaruh secara signifikan terhadap jumlah kasus konfirmasi COVID-19 tiap kabupaten/kota di Pulau Jawa dan Bali sampai dengan masa PPKM Jilid 2.

Secara lebih jelas, persebaran pengelompokkan kabupaten/kota dapat ditunjukkan oleh Gambar 3. Pengelompokkan terbesar yaitu (X1, X2, X4) yang berwarna merah terdapat pada 66 kabupaten/kota dengan variabel kepadatan penduduk (X1), rasio tenaga kesehatan per 1000 penduduk (X2), dan pengeluaran kesehatan per juta rupiah (X4) yang berpengaruh secara signifikan. Kabupaten/kota tersebut tersebar di seluruh Provinsi DI Yogyakarta dan Provinsi Bali, dan juga beberapa kabupaten/kota tersebar di Provinsi Jawa Barat, Provinsi Jawa Tengah, dan Provinsi Jawa Timur. Hal tersebut sejalan dengan beberapa penelitian yang telah dilakukan. Penelitan oleh Mahdy (2020), menyatakan bahwa kepadatan penduduk berpengaruh secara signifikan di Jawa Barat. Penelitian oleh Fitriani dan Jaya (2020), menyatakan bahwa kepadatan penduduk berpengaruh secara signifikan di Jawa Timur. Kemudian, penelitian oleh Marhamah dan Jaya (2020), menyatakan bahwa kepadatan penduduk dan fasilitas pelayanan kesehatan berpengaruh secara signifikan di Kota Bandung, Jawa Barat.

\section{KESIMPULAN}

Berdasarkan hasil dan pembahasan pada bagian sebelumnya, dapat disimpulkan bahwa jumlah kasus konfirmasi COVID-19 di Pulau Jawa dan Bali sampai dengan masa PPKM Jilid 2 memiliki pola yang cenderung menyebar di setiap wilayah. Kabupaten/kota dengan jumlah kasus konfirmasi COVID-19 tinggi ada di Provinsi DKI Jakarta dan sekitarnya. Sementara kabupaten/kota lainnya di Pulau Jawa dan Bali memiliki jumlah kasus konfirmasi COVID-19 yang cenderung rendah. Kemudian, pada data jumlah kasus konfirmasi COVID-19 di Pulau Jawa dan Bali sampai dengan masa PPKM Jilid 2 terdapat keragaman spasial, maka dilakukan pemodelan dengan GWNBR. Pemodelan dengan GWNBR menghasilkan empat kelompok wilayah yang memiliki karakteristik yang sama. Variabel kepadatan penduduk berpengaruh secara signifikan di seluruh kabupaten/kota di Pulau Jawa dan Bali, sedangkan variabel rasio tenaga kesehatan per 1000 penduduk, indeks kualitas udara, dan pengeluaran kesehatan per juta rupiah berpengaruh secara signifikan di beberapa kabupaten/kota di Pulau Jawa dan Bali.

Berdasarkan kesimpulan di atas, adapun saran yang dapat diberikan yaitu mengingat kepadatan penduduk menjadi faktor global yang memengaruhi penambahan kasus konfirmasi COVID-19, maka kebijakan PPKM perlu diterapkan hanya pada wilayah dengan kasus konfirmasi COVID-19 yang tinggi dan sangat tinggi. Kemudian, pemerintah perlu mempertimbangkan karakteristik tiap-tiap kabupaten/kota berdasarkan pengelompokkan faktor-faktor yang memengaruhi kasus konfirmasi COVID-19, sehingga kebijakan yang diambil akan lebih tepat. Penelitian lanjutan dapat dilakukan dengan menggunakan level wilayah yang lebih kecil seperti pada level kecamatan, sehingga analisis yang dihasilkan lebih rinci dalam menjelaskan permasalahan kasus konfirmasi COVID-19. 


\section{DAFTAR PUSTAKA}

Anselin, Luc. (1988). Spatial Econometrics: Methods and Models. Boston: Kluwer Academic.

Berta, Paolo, Paolo Paruolo, Stefano Verzillo, and Pietro Giorgio Lovaglio. (2020). A Bivariate Prediction Approach For Adapting The Health Care System Response To The Spread Of COVID-19. PLoS ONE 15(10): e0240150. https://doi.org/10.1371/journal.pone.0240150

Bowman, A.W., 1984. An alternative method of cross-validation for the smoothing of density estimates. Biometrika, 71 (2), 353-360

Cleveland, W.S., 1979. Robust locally weighted regression and smoothing scatterplots. Journal of the American Statistical Association, 74 (368), 829-836.

Fitriani, Rinda dan I Gede Nyoman Mindra Jaya. (2020). Spatial Modeling Of Confirmed Covid-19 Pandemic In East Java Province By Geographically Weighted Negative Binomial Regression. https://doi.org/10.28919/cmbn/4874

Fotheringham, A., Brunsdon, C. and Charlton, M. (2002). Geographically Weighted Regression: The Analysis of Spatially Varying Relationships. Chichester: John Wiley and Sons Ltd.

Hilbe, Joseph M. (2011). Negative Binomial Regression (2 ${ }^{\text {nd }}$ edition). Cambridge, UK: Cambridge University Press.

Ismail, Noriszura dan Abdul Aziz Jemain. (2007). Handling Overdispersion with Negative Binomial and Generalized Poisson Regression Models. Casualty Actuarial Society Forum, Winter 2007. 103-158.

Kementerian Kesehatan. (2020). Coronavirus Disease COVID-19. Jakarta.

Kementerian Kesehatan. (2020). Panduan Pencegahan Penularan COVID-19 Untuk Masyarakat. https://promkes.kemkes.go.id/panduan-pencegahan-penularan-covid-19-untuk-masyarakat [2 Juni 2021]

Kementerian Kesehatan. (2020). Revisi Ke-5 Pedoman Pencegahan Dan Pengendalian Coronavirus Disease (COVID-19). Jakarta.

Mahdy, Ilham Faishal. (2020). Pemodelan Jumlah Kasus Covid-19 Di Jawa Barat Menggunakan Geographically Weighted Regression. Seminar Nasional Official Statistics 2020: Statistics in the New Normal: A Challenge of Big Data and Officials Statistics.

Marhamah, Elin dan I Gede Nyoman Mindra Jaya. (2020). Modeling Positive Covid-19 Cases In Bandung City By Means Geographically Weighted Regression. https://doi.org/10.28919/cmbn/4991

McCullagh, P.\& Nelder, J.A. (1989). Generalized Linear Models (2 ${ }^{\text {nd }}$ edition). London: Chapman and Hall.

Sekretariat Presiden. (2020). Keterangan Pers Presiden Republik Indonesia. Bogor: Istana Presiden.

World Health Organization. (2020). Coronavirus Disease 2019 (COVID-19). https://www.who.int/emergencies/diseases/ [16 Februari 2021]

Yusa, I Gede Putu Dharma. (2020). Dekomposisi Age Profile Pengeluaran Kesehatan Dan Keterkaitannya Dengan Pandemi COVID-19. Seminar Nasional Official Statistics 2020: Statistics in the New Normal: A Challenge of Big Data and Official Statistics

Zulkarnain, Rizky dan Karuniawati Dewi Ramadani. (2020). Kualitas Udara Dan Potensi Transmisi Covid19 Di Pulau Jawa. Seminar Nasional Official Statistics 2020: Statistics in the New Normal: A Challenge of Big Data and Officials Statistics 